\title{
A CONFERÊNCIA NACIONAL DE EDUCAÇÃO (CONAE) E SUAS FRAGILIDADES
}

\author{
Nicholas Davies ${ }^{1}$ \\ Universidade Federal Fluminense -UFF
}

\begin{abstract}
Examino a seguir alguns aspectos da preparação e do documento final (disponível na página do MEC - www.mec.gov.br) da conferência nacional de educação (CONAE), realizada de 28 de março a $1^{\circ}$ de abril de 2010, com a alegação de elaborar o projeto de um novo plano nacional de educação (PNE), que seria apreciado e aprovado pelo Congresso Nacional para vigorar a partir de 2011. A previsão oficial era que a CONAE seria precedida de conferências municipais/intermunicipais até o primeiro semestre de 2009 e de estaduais até o final de 2009, destinadas a formular propostas a serem encaminhadas e votadas na conferência nacional. Tais conferências prévias à nacional teriam como "subsídio" um documento de referência (DR), aparentemente redigido por uma comissão designada pelo MEC.

Foram muitas as fragilidades destas etapas "preparatórias" e do documento final (DF). Uma é que muitos dos indivíduos e entidades possivelmente interessadas ou capacitadas não foram informadas ou convidadas a participar. Outra é que não se sabe como foram escolhidos os integrantes das comissões municipais ou estaduais. É bastante provável que tenham sido selecionados em função das afinidades pessoais/políticas ou de suas entidades com o governo federal, que patrocinou o evento. A propósito, a conferência aconteceu pouco meses antes da eleição presidencial, sendo, pois, um bom palanque para a candidata do governo federal. Não por acaso o DF da CONAE, pelo menos em seu eixo sobre o financiamento, é quase uma cópia integral do DR, o que permite concluir que a conferência nacional serviu mais para referendar o pacote já elaborado previamente, sob o controle ou pelo menos forte influência do MEC e/ou de indivíduos e entidades que, embora formalmente independentes, estão alinhados com a política do MEC. Em outras palavras, as conferências municipais, intermunicipais, estaduais, e nacional funcionaram apenas e/ou principalmente para legitimar as propostas que vieram de cima para baixo, através do DR.
\end{abstract}

Analiso a seguir alguns aspectos do DF, também presentes no documento de "referência" ("preferência"?). A sua principal fragilidade é não examinar o caráter da sociedade, do Estado, de suas instituições (Legislativo, Judiciário e Executivo) e também dos governos (mesmo os de discurso oportunisticamente progressista) para saber o que esperar deles no caso de um novo PNE, mesmo contendo ingredientes eventualmente progressistas. A história brasileira demonstra que leis e planos ou não são cumpridos ou só o são em função dos interesses dos donos do poder. O PNE sancionado em 2001 e cuja vigência termina no final de 2010 é um exemplo disso.

A deficiência do DF pode ser detectada na maior presença de certos termos do que outros. Enquanto "classes sociais" aparece 3 vezes, e "capitalismo", 2, o termo "diferenças" figura 17 vezes, o que indica a ênfase numa determinada visão pós-moderna que nega ou dilui a identidade de classe e reforça as "múltiplas" identidades específicas, sem nenhuma unidade. Em outras palavras, o DF vê a realidade de modo fragmentado, constituída apenas por identidades particulares e abstratas (mulheres, negros, indígenas, pessoas de orientação sexual nãoconvencional, etc.), como se estas categorias fossem auto-explicativas e/ou determinantes da dinâmica social. Não por acaso uma das mais frequentes "contribuições" do DF é acrescentar o feminino "a" quando o substantivo só mencionava o masculino "o" no DR. Assim, "custo-alunoqualidade" e "professores" no DR foram corrigidos para "custo-aluno(a)-qualidade" e "professores/as" no DF. A falta da análise do caráter do Estado (o Poder "Público") pressupõe que ele poderia, por uma mágica nunca explicada no documento, servir aos interesses da maioria da população ou então à idealizada "sociedade civil". Parece até que o Estado brasileiro não tem

${ }^{1}$ professor da Faculdade de Educação da Universidade Federal Fluminense (UFF) e-mail: nicholas@pq.cnpq.br Revista HISTEDBR On-line, Campinas, n.39, p. 321-345, set.2010 - ISSN: 1676-2584 
nenhuma relação com o capitalismo e com as classes dominantes. Sintomaticamente, a palavra "capitalismo" só aparece de maneira incidental, sem nenhuma importância.

O tom do documento é sobretudo exortativo (com muitas expressões como "é preciso", "é necessário", "urge"), não analítico, criando, pois, a ilusão de que as propostas (pelo menos as principais, relativas ao financiamento) serão encampadas pelo Legislativo e/ou pelo Executivo, mesmo com a pressão das entidades da idealizada "sociedade civil". Este tom exortativo (e não analítico) pode indicar alguns objetivos (obviamente não declarados) dos formuladores do documento: esconder a sua impotência, conquistar e/ou reforçar a legitimidade perante crentes, ingênuos ou espertos, e justificar a ênfase e/ou exclusividade nas lutas institucionais, sobretudo se feitas com dirigentes e assessores pagos pelo dinheiro público ou de sindicalizados.

Outra debilidade é seu caráter vago, genérico e quase sempre sem qualquer fundamentação. Muitas vezes usa palavras que nada significam, como o adjetivo "adequado". Um exemplo é a "participação adequada" dos diferentes níveis de governo no financiamento. Outros exemplos: (1) as receitas da educação devem incluir, "de forma adequada", todos os tributos (impostos, taxas e contribuições); (2) o "Fundeb se pauta pela universalização do atendimento à educação", um equívoco, pois ele não prevê isso, mas apenas a redistribuição de $20 \%$ da maioria dos impostos entre o governo estadual e as prefeituras com base no número de matrículas na educação básica e em pesos diferenciados dessas matrículas; (3) "os conselhos do Fundeb tendem a melhorar a transparência e a fiscalização dos recursos da educação", tendência não justificada pelo DF.

Outra expressão vazia de significado é "qualidade social", um dos objetivos da proposta do novo PNE e mencionado em todo o documento, cujos redatores supõem ou querem supor que "social" se refere a uma parte idealizada da educação ou da sociedade. Aliás, tal expressão já constava do PNE do CONED (Congresso Nacional de Educação, realizado em novembro de 1997 em Belo Horizonte) e até hoje não definida, para comodidade e/ou esperteza dos especialistas em generalidades.

Outra fragilidade é que não faz uma avaliação do PNE de 2001, cujas metas não foram cumpridas em sua maioria. Ora, uma proposta de plano, para ser coerente, deveria partir desta avaliação e indicar concretamente porque inúmeras destas metas não foram até hoje atingidas. Por que investir tempo e energia em mais um plano que provavelmente só vai ficar no papel, a exemplo de tantos outros? Provavelmente apenas para ocupar espaço político, não necessariamente para promover uma educação de qualidade. O documento tampouco explica porque os vetos ao PNE (sobretudo de caráter financeiro) até hoje não foram derrubados pelo presidente Lula, limitando-se a constatar isso.

Outro ponto fraco é o culto exacerbado à legislação, que supostamente resolveria todos ou os principais problemas educacionais. Um exemplo é a ênfase à constituição do sistema nacional articulado de educação e à regulamentação do regime de colaboração entre os entes federativos (União, Estados, DF e Municípios). Sem dúvida, esta regulamentação, se feita e cumprida como prevista na LDB, levaria a uma significativa contribuição do governo federal para sanar as deficiências de Estados e municípios. Entretanto, isso está longe de ser suficiente, por várias razões. Uma é que o Poder "Público" é privatizado de inúmeras maneiras desde sempre, tanto legal, quanto ilegalmente. Uma maneira legal consiste em destinar recursos públicos para financiar empresas privadas (por exemplo, os empréstimos do BNDES). Uma ilegal consiste na corrupção e o desvio de recursos para outros fins que não os legalmente devidos. Por fim, embora o documento ressalte a importância desta regulamentação, não se pergunta por que até hoje a União não se preocupou com isso e por que tem expectativa de que isso venha a ocorrer.

Uma falha adicional é não explicar porque, embora tenha tido 8 anos para isso (20032010), o governo federal, em colaboração com Estados e municípios, não se preocupou em definir o custo-aluno-qualidade (um aspecto muito enfatizado no documento), que seria a referência para o financiamento da educação. Tal custo muito provavelmente não foi definido 
porque exigiria a ação supletiva e redistributiva da União para garantir o padrão mínimo de qualidade. Em outras palavras, demandaria recursos adicionais vultosos da União, cuja contribuição foi insignificante no caso do Fundef (menos de $1 \%$ em 2006) e será modesta no caso do Fundeb (10\% do total a partir de 2010). A contribuição para o Fundeb é modesta porque o governo federal abocanha mais de $60 \%$ da receita tributária nacional, enquanto os Estados e Municípios ficam com menos de $40 \%$.

A parte de financiamento contém várias outras deficiências. Por exemplo, propõe "ampliar o investimento em educação pública em relação ao PIB, na proporção de $1 \%$ ao ano, de forma a atingir no mínimo 7\% do PIB até 2011 e no mínimo 10\% do PIB até 2014." Ora, é impossível cobrar dos governos a aplicação de um percentual do PIB porque eles não arrecadam PIB, mas sim impostos, taxas e contribuições, que correspondem hoje, com base na contabilidade oficial (nada confiável), a cerca de $40 \%$ do PIB. Além disso, como são muitos os governos (1 federal, 26 estaduais, 1 do DF, e 5564 municipais), fica impossível responsabilizar os governos individualmente pela aplicação do percentual do PIB.

A propósito, o documento é inconsistente nesta questão, pois em outro trecho propõe o critério de arrecadação (este sim operacionalizável) dos governos para o financiamento, o que é bem diferente do critério do percentual do PIB. Em outro trecho, propõe algo semelhante ao estipular que a União deveria aplicar no mínimo 25\% (ao invés dos atuais $18 \%$ de impostos) e os Estados, Distrito Federal e Municípios, 30\% (ao invés dos atuais 25\%) de impostos, taxas e contribuições sociais em manutenção e desenvolvimento do ensino. A questão é saber se este critério, também operacionalizável, será aceito politicamente pelos governos, sobretudo o federal, que arrecada mais contribuições do que impostos e taxas. De qualquer modo, a proposta de aumentar os recursos, embora bem vinda, não é garantia de que serão necessariamente aplicados nos fins legalmente devidos e/ou socialmente necessários, conforme é possível constatar pelas inúmeras denúncias de irregularidades que vêm a público. O desafio não é só aumentar os recursos, mas também garantir um controle social efetivo sobre a sua aplicação. Por exemplo, Estados e municípios que receberam significativa complementação federal (dinheiro novo) para o Fundeb desde 2007 até hoje (por exemplo, Alagoas, Bahia, Ceará, Maranhão, Pará, Piauí) registraram diminuição de matrículas no ensino fundamental e no ensino médio no período.

Outro exemplo é a proposta de desvincular os recursos da educação de qualquer nível de contingenciamento e revogar a DRU (Desvinculação da Receita da União, que tirou mais de R\$ 50 bilhões da educação até 2007, segundo o ministro Haddad), mas o documento não se pergunta por que o governo e seus aliados não fizeram isso até então. Ao contrário, o governo Lula prorrogou a DRU por duas vezes (em 2003 e 2007) e só em novembro de 2009 o Congresso Nacional aprovou uma emenda constitucional, a 59, prevendo a sua extinção gradual, começando em 2009 e terminando em 2011. Por que só então? Sensibilidade do governo e de seus parlamentares com a causa educacional? Por que a sensibilidade não se manifestou antes?

Alega ainda o documento que o Fundeb teria valorizado o magistério, porém não apresenta nada que fundamente isso. Afinal, como isso será possível se milhares de prefeituras (e também alguns governos estaduais) perdem na distribuição dos recursos do Fundeb em âmbito estadual? Além disso, o Fundeb não abrange uma série de outros impostos vinculados à educação e, portanto, não poderia ser referência para a valorização do magistério (pelo menos no sentido de melhoria salarial).

Outra fragilidade é atribuir ao Fundeb a virtude de possuir uma visão sistêmica da educação básica, pois compreenderia todos os níveis e modalidades da educação básica. Isso não é verdade porque o Fundeb não enfrenta satisfatoriamente as desigualdades entre regiões, Estados e municípios (o "desequilíbrio regional") que, conforme reconhece o documento, seria um dos desafios do PNE. Até hoje o Fundeb, através da complementação, só vem contribuindo para aumentar os recursos de algumas regiões, Estados e municípios com menos recursos (Pará e Nordeste). O Fundeb tampouco é sistêmico porque atribui, sem nenhuma base em custo-aluno- 
qualidade, diferentes pesos às matrículas dos vários níveis e modalidades da educação básica para a distribuição dos recursos.

Outro problema do documento é semear a ilusão de que órgãos como Ministério Público e Tribunais de Contas (TCs) sejam confiáveis para fiscalizar os recursos. Esta ilusão se explica pelo fato de os redatores do documento nada, pouco conhecerem ou não quererem conhecer sobre a atuação concreta destes órgãos. É sabido que muitos TCs, talvez a imensa maioria, além de não confiáveis ética e politicamente (seus conselheiros são nomeados segundo critérios políticos, não técnicos), adotam as interpretações mais variadas e contraditórias sobre as receitas e despesas em educação, frequentemente as mais favoráveis aos governantes. Para piorar, o documento propõe que a formação dos conselheiros do Fundeb se faça em articulação com os TCs.

Omissões injustificadas, contradições, inconsistências e equívocos não faltam no documento. Declara, por exemplo, que os recursos públicos devem ser dirigidos apenas às instituições públicas, porém é omisso sobre o FIES, que, embora apresentado como um fundo para financiar o estudante das instituições privadas de ensino superior (IES), na verdade contribui para garantir uma clientela relativamente cativa (diminuindo também o número de vagas ociosas) para elas, pois com ele as IES não dependem do pagamento de mensalidades (reduzindo, pois, a inadimplência) pelos estudantes, assegurado pelos certificados do FIES, que as IES utilizam para quitar suas dívidas ao INSS. Ou seja, as IES privadas ganham triplamente: (1) uma clientela cativa; (2) diminuição da capacidade ociosa e da inadimplência; (3) uma receita para pagar as dívidas com o INSS.

O documento se contradiz quando propõe que os recursos públicos sejam aplicados "exclusivamente" nas instituições públicas, porém em outro trecho, ao falar sobre o investimento público no ensino superior, o advérbio muda para "prioritariamente", provavelmente para despistar a contradição do financiamento público às IES privadas através do Prouni (Programa Universidade "Para Todos"), cujo caráter privatizante o documento estranhamente não comenta.

A propósito do Prouni, o documento se equivoca em dizer que ele aumentou os recursos federais em educação, pois ele consistiu apenas na isenção fiscal e de contribuições sociais e/ou previdenciárias a IES privadas em troca de bolsas integrais ou parciais a estudantes cuja renda familiar per capita não ultrapasse 1 salário mínimo e meio (bolsas integrais) ou 3 salários mínimos (bolsas parciais). Portanto, não faz sentido dizer que ele aumentou os recursos federais.

Com relação às isenções fiscais e de contribuições sociais e previdenciárias às instituições privadas de ensino em geral (de todos os níveis) e não apenas no âmbito do Prouni, o DF (assim como o DR) é estranhamente omisso, pois tais isenções representaram e ainda representam um gigantesco financiamento público indireto a elas, que assim deixam de recolher aos cofres públicos tributos que toda empresa é obrigada legalmente a recolher.

Equivoca-se também quando alega que o Fundeb reserva "parcela importante dos recursos para a educação de jovens e adultos" (EJA), pois as matrículas de EJA são as que valem bem menos do que as de qualquer outro nível ou modalidade na distribuição dos recursos do Fundeb, além de ser a única modalidade com um limite máximo do Fundeb (15\%), isso segundo a Lei 11.494/2007, que regulamentou o Fundeb. Se nos basearmos na Medida Provisória 339 (iniciativa do governo federal), que regulamentou provisoriamente o Fundeb em dezembro de 2006, o limite máximo (ou "trava") seria menor ainda: $10 \%$.

Por fim, o documento erra ao dizer que (1) o Fundeb é composto pelo "IPI, exp.", quando o certo é $20 \%$ das cotas estaduais e municipais do IPI-exportação, que correspondem a apenas $10 \%$ de toda a receita deste imposto, pois $90 \%$ ficam com o governo federal; (2) o IPVA, o ITBI e o ITR fazem parte do Fundeb, quando o correto é $20 \%$ do IPVA, ITCD (o ITBI é imposto municipal e não entra no Fundeb), e $20 \%$ da cota municipal do ITR (= 50\%), pois 50\% correspondem à cota federal; (3) devem ser acrescentados ao Fundeb "25\% de impostos estaduais próprios", quando o correto seria dizer impostos estaduais próprios não incluídos no Fundeb (o imposto de renda dos servidores estaduais, por exemplo), pois, no caso de impostos 
estaduais próprios incluídos no Fundeb (ICMS, IPVA, ITCD), o percentual é 5\% (isso, se a Constituição Estadual estipular o percentual mínimo de 25\%); (4) os municípios podem demandar recursos do fundo de manutenção e desenvolvimento da educação superior pública, quando o artigo 11 da LDB prevê que os municípios só poderão atuar em níveis ulteriores à educação infantil (EI) e ao ensino fundamental (EF) depois de atendida plenamente a demanda na EI e no EF e, mesmo assim, com percentuais acima dos $25 \%$ dos impostos. Além disso, no caso de receitas, o documento omitiu as adicionais ao mínimo, como o ganho com o Fundeb, o salário-educação, e transferências federais para programas como o de alimentação escolar, transporte escolar, etc.

Em síntese, essas e muitas outras fragilidades (e também do processo de realização das conferências) mostram que a Conae esteve longe de ser democrática e de pretender resolver seriamente os principais problemas da educação, sendo apenas mais uma tentativa de mobilização de forças pró-governo na campanha para as eleições presidenciais em 2010 e de legitimação das iniciativas governamentais, com o apoio de sindicatos, ONGs, entidades e intelectuais de discurso progressista.

\section{Referências}

BRASIL. Presidência da República. MEC. Secretaria Executiva. CONAE 2010. Construindo o Sistema Nacional Articulado de Educação: o Plano Nacional de Educação, Diretrizes e Estratégias de Ação. Documento-Referência. Brasília, s.d. Disponível em: $<$ http://www.mec.gov.br>. Acesso em: mar. 2010.

BRASIL. Presidência da República. MEC. Secretaria Executiva. [CONAE 2010]. DocumentoFinal. Brasília, 2010. Disponível em: <http://www.mec.gov.br>. Acesso em: jul. 2010.

DAVIES, Nicholas. Financiamento da educação: novos ou velhos desafios? São Paulo: Xamã, 2004.

DAVIES, Nicholas. Fundeb: a redenção da educação básica? Campinas, SP: Editora Autores Associados, 2008. 


\section{COMPARAÇÃO DO EIXO “FINANCIAMENTO DA EDUCAÇÃO” NO DOCUMENTO DE REFERÊNCIA (DR, fora de caixa) E NO DOCUMENTO FINAL (DF, dentro de caixa) DA CONAE*}

DR - 210 A Constituição Federal de 1988 estabeleceu que a educação é um direito social e definiu que os responsáveis pelo seu provimento são o Estado e a família. Para resguardar o direito à educação, o Estado estabeleceu a estrutura e as fontes de financiamento. Ao determinar a vinculação de recursos financeiros para a educação, a Constituição garantiu percentuais mínimos da receita resultante de impostos à manutenção e desenvolvimento do ensino: 18\% da receita da União e $25 \%$ da receita dos estados, Distrito Federal e municípios, incluindo-se as transferências ocorridas entre esferas de governo e o salário-educação. ${ }^{* * *}$

DF - A Constituição Federal de 1988 estabeleceu que a educação é um direito social e definiu que os/as responsáveis pelo seu provimento são o Estado e a família. Para resguardar o direito à educação, o Estado estabeleceu a estrutura e as fontes de financiamento. Ao determinar a vinculação de recursos financeiros para a educação, a Constituição garantiu percentuais mínimos da receita, $[\mathrm{sic}]$ resultantes de impostos, [sic] à manutenção e desenvolvimento do ensino: $18 \%$ da receita de impostos da União e $25 \%$ da receita de impostos dos estados, Distrito Federal e municípios, incluindo-se as transferências ocorridas entre esferas de governo e o salárioeducação.**

211 O conceito expresso na Constituição Federal assevera, portanto, que o financiamento adequado das políticas educacionais se traduz em alicerce para a construção do sistema nacional articulade de educação e, consequientemente, para o alcance das metas contidas em planos nacionais como o Plano Nacional de Educação (PNE). Contudo, para o acesso eqüitativo e universal à educação básica e a elevação substancial de alunøs matriculados na educação superior pública, urge aumentar o montante estatal de recursos investidos na área, além de solucionar edesequilíbrio regional.

O conceito expresso na Constituição Federal assevera, portanto, que o financiamento adequado das políticas educacionais se traduz em alicerce para a construção do Sistema Nacional de Educação e, consequentemente, é imprescindível para assegurar o alcance das metas contidas em planos nacionais, como o Plano Nacional de Educação (PNE). Contudo, para o acesso equitativo e universal à educação básica de qualidade e para a garantia de permanência e sucesso escolar de crianças, jovens e adultos que cursam as etapas e modalidades de ensino que a integram, além da elevação substancial de estudantes matriculados/as na educação superior pública, urge aumentar o montante estatal de recursos investidos na área, principalmente em relação à contribuição da União, além de solucionar a desigualdade regional.

212 Como primeiro passo rumo à superação dessa realidade, faz-se necessária a elaboração e aprovação de uma reforma tributária pautada pela justiça social e o equilíbrio regional e preocupada, primordialmente, em garantir recursos financeiros para a efetivação de direitos sociais e distribuição de renda. Essa reforma deve ser capaz de vincular de forma adequada os

\footnotetext{
* Segundo a CO (Comissão Organizadora) da Conae, o DR teria sido elaborado para subsidiar as conferências (municipais, intermunicipais e estaduais) que precederam a Conferência Nacional. Os documentos foram obtidos no portal do MEC: www.mec.gov.br. Os parágrafos do documento final (DF) estão dentro de caixa e as suas alterações e acréscimos em relação ao DR são assinaladas em negrito. Indico, também, alguns equívocos dos documentos. Os trechos riscados do DR foram suprimidos no DF.

*** Equívoco: o salário-educação é contribuição social e não faz parte do cálculo do percentual mínimo.
} 
tributos (impostos, taxas e contribuições) ao investimento educacional, de tal modo que as políticas de renúncia e guerra fiscal não prejudiquem o financiamento público da educação.

Como primeiro passo rumo à superação dessa realidade, faz-se necessário assegurar a elaboração e aprovação de uma reforma tributária transparente, no prazo máximo de três anos, pautada pela justiça social e o equilíbrio regional e preocupada, primordialmente, em garantir recursos financeiros suficientes e permanentes para a efetivação de direitos sociais e distribuição de renda. Essa reforma deve ser capaz de vincular de forma adequada todos os tributos (impostos, taxas e contribuições) ao investimento educacional, de tal modo que as políticas de renúncia e guerra fiscal não prejudiquem o financiamento público da educação.

Necessita garantir também que as perdas de recursos educacionais advindos das renúncias ou isenções fiscais sejam recuperadas e garantidas em rubricas orçamentárias educacionais. Deve, também, alterar as disposições da Lei de Responsabilidade Fiscal (LRF), retirando as despesas com recursos humanos pagas com dotações financeiras advindas do Fundeb do somatório do total gasto com pessoal. Com isso, não fica comprometido, portanto, o limite máximo de $54 \%$ da receita corrente líquida que devem ser investidos em pessoal pela referida lei.

213 Como alternativa ao ${ }^{*}$ atual desequilíbrio regional e à ${ }^{* *}$ oferta de educação básica pública o financiamento à educação deve tomar como referência o mecanismo do custo-aluno qualidade (CAQ). Previsto no ordenamento jurídico brasileiro, o CAQ deve ser definido a partir do custo anual por aluno dos insumos educacionais necessários para que a educação básica pública adquira padrão mínimo de qualidade. A construção do CAQ exige amplo debate sobre o número de alunos por turma, remuneração adequada e formação continuada aos profissionais da educação, condições de trabalho aos professores e funcionários, materiais necessários à aprendizagem dos estudantes (como salas de informática, biblioteca, salas de ciência etc ). Em suma, deve considerar o conjunto dos insumos exigidos para a adequada relação de ensinoaprendizagem nas escolas públicas brasileiras que oferecem a educação básica.

Como alternativa ao* atual desequilíbrio regional e à** oferta de educação básica pública, o financiamento à educação deve tomar como referência, e em caráter de urgência, o mecanismo do custo aluno/a-qualidade (CAQ). Previsto no ordenamento jurídico brasileiro, o CAQ deve ser definido a partir do custo anual por estudante dos insumos educacionais necessários para que a educação básica pública adquira e se realize com base em um padrão mínimo de qualidade. A construção do CAQ exige amplo debate sobre o número de estudantes por turma, remuneração adequada e formação continuada aos/às profissionais da educação, condições de trabalho aos/às professores e funcionários/as, materiais necessários à aprendizagem dos/das estudantes (como salas de informática, biblioteca, salas de ciência, quadra poliesportiva, oficinas de música e de artes, mobiliário adequado, além de sala de recursos para apoio pedagógico a estudantes com dificuldade de aprendizagem etc) Em suma, deve considerar o conjunto dos insumos exigidos para a adequada relação de ensino-aprendizagem nas escolas públicas brasileiras que oferecem a educação básica No esforço para a implementação do CAQ as escolas com menos acesso a esses recursos devem ser tornadas prioritárias, levando em consideração, principalmente, a diversidade e as desigualdades regionais e suas peculiaridades.

É preciso considerar ainda um valor diferenciado para os estabelecimentos que atendam crianças, adolescentes, jovens e adultos com desafios de inclusão, como pessoas com deficiência, populações do campo, populações ribeirinhas, quilombolas e indígenas. Para atender adequadamente esses grupos, entre outras medidas, como financiamento adequado

\footnotetext{
* sic - o certo é 'para o'.

** sic - o certo é 'para a'.
}

Revista HISTEDBR On-line, Campinas, n.39, p. 321-345, set.2010 - ISSN: 1676-2584 
à [sic] políticas de formação adequada dos/as profissionais da educação, é preciso adequar e reestruturar os prédios, atendendo também às necessidades educacionais relacionadas à educação inclusiva, além de disponibilizar mobiliário adequado, respeitando a ergonomia, faixa etária dos estudantes atendidos e oferta de merenda escolar de qualidade que atenda às necessidades de todos/as os/as educandos/as.

O CAQ deve ser formalmente definido no prazo máximo de um ano a partir da aprovação desse documento $\mathrm{E}$ deve também ser dada publicidade ao $\mathrm{CAQ}$, propiciando uma ampla fiscalização social em sua implementação Para tal é necessário realizar e divulgar estudos sobre os custos adequados da educação básica nas suas diferentes etapas e modalidades, com base em padrões mínimos de qualidade, com vistas a melhorar a eficiência e garantir a generalização da qualidade do atendimento. Deve caber à União a complementação de recursos financeiros a todos os estados e aos municípios que não conseguirem atingir o valor do CAQ.

214 A elevação do quantitativo de estudantes matriculados na educação superior pública exige, além da execução completa do Plano de Reestruturação e Expansão das Universidades Federais (Reuni), a elaboração de indicadores de acompanhamento da qualidade das universidades federais em que sejam explicitadas as evoluções do custo do aluno, condições de funcionamento dos programas de pós-graduação stricto-sensu, abertura de novos programas de pós-graduação, apoio ao desenvolvimento de pesquisas, definidas no contexto da autonomia de cada uma das universidades, e programas que apóiem a permanência de estudantes nas instituições.

A ampliação do quantitativo do número de vagas na educação superior pública exige, além do aperfeiçoamento, democratização, execução ampliada e superação dos limites do Plano de Reestruturação e Expansão das Universidades Federais (Reuni), a implementação de outros programas de expansão democraticamente discutidos com a comunidade universitária e com a sociedade local, para que esta seja feita com garantia e elevação da qualidade Tal preocupação se estende à criação de novas instituições e cursos, que devem ser resultado de um processo que leve em consideração as reais necessidades da população das diferentes regiões do País. Exige, também, a elaboração de indicadores de acompanhamento da qualidade das universidades públicas, especialmente as federais, em que sejam explicitadas as evoluções do custo do/da estudante/ano; as condições de funcionamento dos programas de pós-graduação stricto sensu; a imprescindível abertura de novos programas de pós graduação stricto sensu; apoio ao desenvolvimento de pesquisas, definidas no contexto da autonomia de cada uma das universidades; programas que apóiem a permanência de estudantes nas instituições; além da oferta de pós-graduação lato sensu, garantindo-se a gratuidade para todos os interessados.

215 Os dirigentes da educação dos níveis de governo federal, estadual/DF e municipal, ao estabelecerem ações coordenadas com vistas à elaboração de uma agenda mínima de fortalecimento da educação básica, considerando a organização dos trabalhadores em educação, articulada aos demais segmentos da sociedade, delinearam ações que provocaram avanços nas políticas educacionais.

Os/As dirigentes da educação dos níveis de governo federal, estadual, distrital e municipal, articulados com os demais segmentos e setores da sociedade civil, em especial com os/as trabalhadores/as da educação, estabeleceram ações coordenadas com vistas à elaboração de uma agenda mínima de fortalecimento da educação básica e superior e delinearam ações que provocaram avanços nas políticas educacionais. 
216 Nas últimas décadas, portanto, no âmbito das políticas educacionais, destacaram- se, sobremaneira, as modificações de ordem jurídico-institucional. Após a aprovação da Constituição Federal de 1988, quatre textos legais foram de grande importância para a área educacional: a aprovação da LDB (Lei no 9.394/96) e do PNE (Lei $\left.n^{\circ} 10.172 / 01\right)$, bem como a instituição do Fundef, alterado pela aprovação da Emenda Constitucional $n^{\circ} 53$ e da Lei $n^{\circ}$ 11.494, de 2007, que respectivamente eriou e regulamentou o Fundo de Manutenção e Desenvolvimento da Educação Básica e de Valorização dos Profissionais da Educação (Fundeb).

Nas últimas décadas, portanto, no âmbito das políticas educacionais, destacaram-se as modificações de ordem jurídico-institucional. Após a aprovação da Constituição Federal de 1988, cinco textos legais foram de grande importância para a área educacional: a aprovação da LDB (Lei no 9394/96) e do PNE (Lei no 10172/01), bem como a instituição do Fundef, alterado pela aprovação da Emenda Constitucional (EC) $n^{\circ}$ 53/2006 e da Lei $n^{\circ} 11494 / 2007$, que respectivamente criaram e regulamentaram o Fundo de Manutenção e Desenvolvimento da Educação Básica e de Valorização dos/das Profissionais da Educação (Fundeb), além da EC $59 / 2009$.

217 As ações governamentais na educação superior pública federal, principalmente a partir de 2005, significaram também uma elevação dos recursos financeiros aplicados em educação. As seguintes ações contribuíram para esse fato:

- a implantação do Programa Universidade para Todos (ProUni) em 2005;

- a iniciativa de recuperar os valores gastos em outros custeios e investimentos nas instituições federais de ensino superior;

- a expansão dos campi das universidades federais estabelecidos no interior dos estados, em 2006;

- e o início da implantação do Programa de Reestruturação e Expansão das Universidades Federais (Reuni), em 2007/2008, que, até 2012, expandirá as vagas de graduação presenciais de 133.941, em 2007, para 227.260, em 2012.

As ações governamentais na educação superior pública federal, principalmente a partir de 2005, significaram também uma elevação dos recursos financeiros aplicados em educação. As seguintes ações contribuíram para esse fato:

- a implantação do Programa Universidade para Todos (ProUni) em 2005, acompanhada de seu respectivo órgão de controle social, a Comissão Nacional de Acompanhamento e Controle Social (Conap) do Prouni, estabelecida em 2006;

- a iniciativa de recuperar os valores gastos em outros custeios e investimentos nas instituições federais de ensino superior;

- a expansão dos campi das universidades federais estabelecidos no interior dos estados, em 2006;

- e o início da implantação do Programa de Reestruturação e Expansão das Universidades Federais (Reuni), em 2007/2008, que, até 2012, expandirá as vagas de graduação presenciais de 133.941, em 2007, para 227.260, em 2012.

218 Apesar desses avanços, o debate sobre o financiamento da educação é central e envolve a solução de alguns nós críticos:

- revisão do papel da União no financiamento da educação básica;

- instituição de um verdadeiro regime de colaboração entre os entes federados;

- estabelecimento de uma real valorização dos (as) trabalhadores(as) em educação;

- definição de referenciais de qualidade para todos os níveis e modalidades de educação/ensino; 
- e definição do papel da educação superior pública no processo de desenvolvimento do País.

Apesar desses avanços, o debate sobre o financiamento da educação é central e envolve a solução de alguns nós críticos:

- a revisão do papel da União no financiamento da educação básica;

- a instituição de um verdadeiro regime de colaboração entre os entes federados;

- o estabelecimento de uma real valorização dos trabalhadores em educação;

- a definição de referenciais de qualidade para todos os níveis e modalidades de educação/ensino; - e a definição do papel da educação superior pública no processo de desenvolvimento do País.

Além disso, é preciso determinar que o orçamento da educação seja administrado sempre pelas secretarias de educação e não pelas secretarias de governo, fazenda ou suas correlatas. Nesse contexto, é fundamental a criação e instituição da Lei de Responsabilidade Educacional e alterações de dispositivos da LRF que limitam os avanços na área da educação.

219 Enquanto a LDB reestruturou e definiu as diretrizes e bases da educação brasileira após o regime militar, o PNE apontou novos rumos para as políticas e ações governamentais na chamada "Década da Educação". Agregou-se a essas mudanças a pesterior definição implantação do Plano de Desenvolvimento da Edueação (PDE), com açẽes específicas para elevar a qualidade da educação. Além de atuar para que as metas do PNE sejam aleançadas, os programas previstos no PDE abrangem todos os níveis educacionais. Há, portanto, neste momento, a necessidade de se efetivar e publicizar uma avaliação do PNE, como prioridade, tendo em vista o término da "Década da Educação", em 2011.

Enquanto a LDB reestruturou e definiu as diretrizes e bases da educação brasileira após o regime militar, o PNE apontou novos rumos para as políticas e ações governamentais na chamada "Década da Educação". No entanto, o PNE sofreu vetos que o descaracterizaram e não houve esforço governamental efetivo (nas três esferas de governo) para sua implementação. Há, portanto, neste momento, a necessidade de se efetivar e publicizar uma avaliação do PNE, como prioridade, tendo em vista o término da "Década da Educação", em 2010, e a elaboração do novo PNE, iniciada pela Conae.

$220 \mathrm{O}$ alcance das metas estipuladas no PNE, na perspectiva de garantia do direito a uma educação com qualidade social, requer ações governamentais ousadas, que revoguem os vetos presidenciais apostos ao PNE. Especificamente no setor público, a CF/1988 e a LDB/199 atribuíram à União, aos estados, ao Distrito Federal e aos municípios a responsabilidade pela administração do sistema educacional brasileiro. Daí a exigência de um sistema nacional de educação articulado, norteado pela firme concepção da educação como direito humano fundamental, direito público e dever do Estado. Sua operacionalização não pode prescindir da regulamentação do regime de colaboração entre as instâncias federadas - o que, certamente, ensejará o estabelecimento de marcos teórico-conceituais na organização, na gestão e no real alcance do papel dos entes, por seu caráter descentralizado.

O alcance das metas estipuladas no PNE, na perspectiva de garantia do direito a uma educação com qualidade social, requer ações governamentais ousadas, que revoguem os vetos presidenciais apostos ao PNE atual. Especificamente no setor público, a CF/1988 e a LDB/1996 atribuíram à União, aos estados, ao Distrito Federal e aos municípios a responsabilidade pela administração do sistema educacional brasileiro. Daí a exigência de um sistema nacional de educação articulado, norteado pela firme concepção da educação como direito humano fundamental, direito público e dever do Estado. Sua operacionalização não pode prescindir da 
regulamentação do regime de colaboração entre as instâncias federadas - o que, certamente, ensejará o estabelecimento de marcos teórico-conceituais na organização, na gestão e no real alcance do papel dos entes, por seu caráter descentralizado.

221 Apesar dos recentes avanços conquistados pela sociedade brasileira nos termos do ordenamento jurídico relativo às políticas educacionais, o esforço para o cumprimento das metas do PNE ficarão [sic] gravemente prejudicados se alguns pontos críticos complementares e interdependentes não forem superados:

a) Regulamentação do Art. 211 da Constituição Federal, que trata do Regime de Colaboração;

b) Redefinição do modelo de financiamento da educação, considerando a participação adequada dos diferentes níveis de governo (federal, estaduais, distrital e municipais) relativa aos investimentos nas redes públicas de educação;

c) Estabelecimento de referenciais de qualidade para todos os níveis educacionais;

d) Definição do papel da educação superior pública no processo de desenvolvimento do País, além do estabelecimento da autonomia universitária com adequado financiamento (Artigo 55 da LDB);

e) Aprimoramento dos mecanismos de acompanhamento e avaliação da sociedade no que tange ao financiamento da educação.

Apesar dos recentes avanços conquistados pela sociedade brasileira nos termos do ordenamento jurídico relativo às políticas educacionais, o esforço para o cumprimento das metas do PNE ficará gravemente prejudicado se alguns pontos críticos complementares e interdependentes não forem garantidos :

a) Regulamentação do Art. 211 da Constituição Federal, que trata do Regime de Colaboração.

b) Redefinição do modelo de financiamento da educação, considerando a participação adequada dos diferentes níveis de governo (federal, estaduais, distrital e municipais) relativa aos investimentos nas redes públicas de educação.

c) Estabelecimento de referenciais de qualidade para todos os níveis educacionais.

d) Definição do papel da educação superior pública no processo de desenvolvimento do País, além do estabelecimento da autonomia universitária com adequado financiamento (Artigo 55, LDB).

e) Aprimoramento dos mecanismos de acompanhamento e avaliação da sociedade no que tange ao financiamento da educação, como: ampla divulgação do orçamento público; acesso aos dados orçamentários e transparência nas rubricas orçamentárias; e articulação entre as metas do PNE e os demais instrumentos orçamentários da União, estados, Distrito Federal e municípios.

f) Regulamentação do setor privado.

g) Instituição, como política de Estado, da compulsoriedade de administração de todos os recursos da educação em contas específicas exclusivas em todos os níveis (federal, estadual, distrital e municipal).

h) Aplicação dos recursos públicos exclusivamente nas instituições públicas de ensino.

222 Há que se problematizar, também, o papel de cada instância e os marcos jurídicos que normatizam a ação da União, dos estados, do Distrito Federal e dos municípios junto à educação básica, que deve ser universalizada e obrigatéria, bem como em relação à educação superior pública, que deve ser expandida e devidamente financiada, considerando-se que diverses estudes acadêmicos mostram que o número de famílias brasileiras que podem arear com o pagamento de mensalidades no setor privado já atingiu o limite

máximo. 
Há que se problematizar, também, o papel de cada instância e os marcos jurídicos que normatizam a ação da União, dos estados, do Distrito Federal e dos municípios junto à educação básica, que deve ser universalizada, bem como em relação à educação superior pública, que deve ser expandida e devidamente financiada. Para tanto, é imprescindível que o investimento público no ensino superior seja direcionado, prioritariamente, à ampliação e qualificação de oferta pública no Brasil.

223 Considerando que cabe à União liderar o esforço de aumentar o investimento em educação em relação ao PIB, há que se estabelecer estratégias nacionais, ensiderande-se a ação conjunta da União, estados, DF e municípios e que este esforço seja proporcional à respectiva participação na arrecadação nacional, levando-se em conta as responsabilidades constitucionais de cada ente da federação.

Considerando que cabe à União liderar o esforço em aumentar o investimento em educação em relação ao PIB, há que se estabelecer estratégias nacionais, compreendendo-se a ação conjunta da própria União, dos estados, DF e municípios. Este esforço deve ser proporcional à respectiva participação de cada um na arrecadação nacional, levando-se em conta as responsabilidades constitucionais de cada ente da federação. Portanto, é preciso definir o papel da União em todas as modalidades e níveis de ensino (educação básica e ensino superior), e não somente os papéis dos estados e municípios. Faz-se necessário, também, regulamentar o ensino privado em todos os níveis educacionais, limitando a participação de capital estrangeiro na educação, retomando os marcos da educação como direito e não como mercadoria, garantindo fiscalização efetiva para evitar abusos.

224 Todas essas questões identificam-se com a efetivação do Sistema Nacional de Educação (SNE) e o redirecionamento dos processos de organização e gestão, para lograr a qualidade social em todos os níveis e modalidades da educação brasileira. Em um país fortemente marcado por disparidades regionais, elas evidenciam a importância do estabelecimento de políticas nacionais.

Todas essas questões identificam-se com a efetivação do Sistema Nacional de Educação e o redirecionamento dos processos de organização e gestão, para lograr a qualidade social em todos os níveis e modalidades da educação brasileira. Em um país fortemente marcado por disparidades regionais, elas evidenciam a importância do estabelecimento de políticas nacionais por meio da participação na elaboração do orçamento, planejamento e acompanhamento dos recursos a serem investidos na educação, visando a descentralizar, democratizar e desburocratizar tais recursos; devidamente [sic] de forma [sic] articuladas com políticas estaduais, municipais, distritais e regionais, mediante práticas de colaboração.

225 O financiamento da educação constitui tarefa complexa, devido ao envolvimento entre os diferentes entes federados e a esfera privada, bem como à falta de regulamentação do regime de colaboração entre os entes, à ambígua relação entre o público e o privado, à necessidade de implementação de uma gestão democrática. A esses aspectos, somam-se a urgência na definição de parâmetros que estabeleçam a qualidade da educação e, em específico, o critério custo-alunoqualidade em todos os níveis educacionais, e que dificulta o processo de otimizaçãa das políticas de financiamento e de gestão transparente no uso,

bem como na definição e aplicação de recursos.

O financiamento da educação constitui tarefa complexa, devido ao envolvimento entre os diferentes entes federados e a esfera privada, bem como à falta de regulamentação do regime de 
colaboração entre os entes, à ambígua relação entre o público e o privado e à necessidade de implementação de uma gestão democrática. Desse modo, deve ser estabelecida lei específica que defina as competências, a participação nos investimentos educacionais e as demais responsabilidades de cada ente federado e devem ser estabelecidos meios de controle e medidas de punição no caso de descumprimento desse dispositivo legal. A esses aspectos, somam-se a urgência na definição de padrões mínimos que estabeleçam referenciais para a qualidade da educação e, em específico, o critério custo-aluno/a qualidade em todos os níveis, etapas e modalidades educacionais.

226 Apesar da dificuldade para definir o custo aluno-qualidade (CAQ) na educação básica, é possível inferir com base em estudos realizados no Brasile diante dos valores investidos por países dotados de sistemas educacionais mais desenvolvidos, que os valores por aluno praticados atualmente são significativamente inferiores aos requeridos à infra-estrutura adequada a um ensino de qualidade. Urge aumentar os valores aplicados, por aluno, destinados à manutenção e ao desenvolvimento da educação básica pública, para fazer face aos inúmeros desafios, tais como: a remuneração condigna dos profissionais da educação; a formação continuada e adequada dos trabalhadores em educação; a oferta correspondente à demanda por transporte escolar; a correção da relação de alunos por sala de aula; além da oferta de insumos, essenciais a uma boa relação de ensino-aprendizagem nas escolas da educação básica.

Atualmente, os gastos por aluno/a-ano dos níveis e modalidades da educação, especialmente na educação básica, são significativamente inferiores aos requeridos para os insumos adequados a um ensino de qualidade. Urge aumentar os valores aplicados, por estudante, destinados à manutenção e ao desenvolvimento da educação básica pública, para fazer face aos inúmeros desafios, tais como: a remuneração condigna dos/das profissionais da educação; a formação continuada e adequada dos/das trabalhadores/as em educação; a oferta correspondente à demanda por transporte escolar; a correção da relação de estudantes por sala de aula; a oferta de insumos (profissionais qualificados e recursos materiais), essenciais a uma boa relação de ensino-aprendizagem nas escolas da educação básica.

$227 \mathrm{Na}$ educação superior, é fundamental a efetivação da autonomia universitária constitucional, bem como a expansão das vagas em cursos presenciais e o aporte de recursos financeiros especiais para a pesquisa e pós-graduação stricto sensu, de modo a alterar o ambiente heterônomo em que as instituições se encontram.

Na educação superior, é fundamental a efetivação da autonomia universitária constitucional, bem como a expansão das vagas em cursos presenciais e o aporte de recursos financeiros especiais para a pesquisa e pós-graduação stricto sensu e lato sensu, de modo a alterar o ambiente heterônomo em que as instituições se encontram.

228 O financiamento da educação envolve a definição das condições materiais e de recursos para a formulação, implantação e avaliação das políticas educacionais e dos programas e ações a elas relacionados. Também envolve os processos de gestão, acompanhamento, controle e fiscalização dos recursos Tudo isso deve trazer de volta a reflexão sobre a necessidade de sua vinculação ao produto interno bruto (PIB), em percentuais bem acima dos hoje praticados, dado que os atuais se mostram insuficientes ao ressarcimento da dívida histórica do Estado para com a educação brasileira.

O financiamento da educação envolve a definição das condições materiais e de recursos para a formulação, implantação e avaliação das políticas educacionais e dos programas e ações a elas 
relacionados. Também envolve os processos de gestão, acompanhamento, controle e fiscalização dos recursos. Tudo isso deve trazer de volta a reflexão sobre a necessidade de sua vinculação ao produto interno bruto (PIB), em percentuais bem acima dos praticados hoje, dado que os atuais se mostram insuficientes ao ressarcimento da dívida histórica do Estado para com a educação brasileira.

229 A política de financiamento da educação básica, nos termos de um sistema nacional articulado de educação, deve amparar-se na definição de um custo aluno-qualidade (CAQ), construído com a participação da sociedade civil, capaz de mensurar todos os insumos necessários à educação de qualidade, com ênfase no investimento à valorização de todos os profissionais da educação básica.

A política de financiamento da educação básica, nos termos de um sistema nacional de educação, deve, obrigatoriamente, amparar-se na definição de um custo aluno/a-qualidade (CAQ), construído com a participação da sociedade civil, capaz de mensurar todos os insumos necessários à educação de qualidade, superando as desigualdades regionais, com ênfase no investimento à valorização de todos/as os/as profissionais da educação básica.

230 Prioritariamente, o regime de colaboração entre os sistemas de ensino, tendo como um dos instrumentos o financiamento da educação, não pode prescindir das seguintes ações:

a) Regulamentar o regime de colaboração entre os entes federados previsto na Constituição Federal, estabelecendo o direito à educação gratuita e de qualidade social em todas as esferas administrativas, com garantia das devidas condições para o seu funcionamento;

b) Construir o regime de colaboração entre os órgãos normativos dos sistemas de ensino, fortalecendo a cultura do relacionamento entre o Conselho Nacional de Educação, os conselhos estaduais e municipais de educação;

c) Ampliar o investimento em educação pública em relação ao PIB, na proporção de $1 \%$ ao ano, de forma a atingir, no mínimo, 7\% do PIB até 2011 e, no mínimo, 10\% do PIB até 2014, respeitando a vinculação de receitas à educação definidas e incluindo, de forma adequada, todos os tributos (impostos, taxas e contribuições);

d) Definir e aperfeiçoar os mecanismos de acompanhamento, fiscalização e avaliação da sociedade, articulados entre os órgãos responsáveis (conselhos, Ministério Público, Tribunal de Contas), para que seja assegurado o cumprimento da aplicação dos percentuais mínimos na manutenção e desenvolvimento do ensino;

e) Ampliar o atendimento dos programas de renda mínima associados à educação, a fim de garantir o acesso e a permanência na escola a toda população;

f) Estabelecer política nacional de gestão educacional, com mecanismos e instrumentos que contribuam para a democratização da escola e do ensino; assegure a elaboração e implementação de planos estaduais e municipais de educação; e articule a construção de projetos políticopedagógicos escolares, sintonizados com a realidade e as necessidades locais;

g) Promover a autonomia (pedagógica, administrativa e financeira) das escolas, bem como o aprimoramento dos processos de gestão, para a melhoria de suas ações pedagógicas;

h) Criar instrumentos que promovam a transparência na utilização dos recursos públicos pelos sistemas de ensino e pelas escolas, para toda a comunidade local e escolar;

i) Estabelecer mecanismos democráticos de gestão que assegurem a divulgação, a participação e a socialização na elaboração e implementação de planos estaduais e municipais de educação, bem como de projetos político-pedagógicos escolares;

j) Definir financiamento, em regime de colaboração, para políticas e estratégias de solução dos problemas do transporte escolar, enfrentados, principalmente, pelos municípios, em relação ao gerenciamento e pagamento das despesas; 
k) Orientar os conselhos municipais de educação para que se tornem órgãos normatizadores do ensino público municipal e das instituições privadas de educação infantil, no contexto do SNE.

Prioritariamente, o regime de colaboração entre os sistemas de ensino, tendo como um dos instrumentos o financiamento da educação, não pode prescindir das seguintes ações:

a) Regulamentar o regime de colaboração entre os entes federados previsto na Constituição Federal, estabelecendo o direito à educação gratuita e de qualidade social em todas as esferas administrativas, com garantia das devidas condições para o seu funcionamento.

b) Construir o regime de colaboração entre os órgãos normativos dos sistemas de ensino, fortalecendo a cultura do relacionamento entre o Conselho Nacional de Educação, os conselhos estaduais, distrital e municipais de educação.

c) Ampliar o investimento em educação pública em relação ao PIB, na proporção de, no mínimo, $1 \%$ ao ano, de forma a atingir, no mínimo, $7 \%$ do PIB até 2011 e, no mínimo, $10 \%$ do PIB até 2014, respeitando a vinculação de receitas à educação definidas e incluindo, de forma adequada, todos os tributos (impostos, taxas e contribuições).

d) Definir e aperfeiçoar os mecanismos de acompanhamento, fiscalização e avaliação da sociedade, articulados entre os órgãos responsáveis (conselhos, Ministério Público, Tribunal de Contas), para que seja assegurado o cumprimento da aplicação dos percentuais mínimos na manutenção e desenvolvimento do ensino (MDE), garantindo que os percentuais mínimos vinculados à MDE nas constituições estaduais e leis orgânicas municipais e Distrital sejam respeitados pelo executivo, sob fiscalização adequada dos tribunais de contas, especialmente nos estados, Distrito Federal, e municípios que têm previsto uma vinculação mínima superior aos $25 \%$;

e) Ampliar o atendimento dos programas de renda mínima associados à educação, a fim de garantir o acesso e a permanência na escola a toda população.

f) Estabelecer política nacional de gestão educacional, com mecanismos e instrumentos que contribuam para a democratização da escola e do ensino, assegurando a elaboração e implementação de planos estaduais, distrital e municipais de educação e articulando a construção de projetos político-pedagógicos escolares, sintonizados com a realidade e as necessidades locais.

g) Garantir a autonomia (pedagógica, administrativa e financeira) das escolas, bem como o aprimoramento dos processos de gestão, para a melhoria de suas ações pedagógicas.

h) Criar instrumentos que promovam a transparência na utilização dos recursos públicos e sua divulgação pelos sistemas de ensino e pelas escolas, para toda a comunidade local e escolar.

i) Estabelecer mecanismos democráticos de gestão que assegurem a divulgação, a participação e a socialização na elaboração e implementação de planos estaduais, distrital e municipais de educação, bem como de projetos político-pedagógicos escolares.

j) Definir financiamento, em regime de colaboração, para políticas e estratégias de solução dos problemas do transporte escolar, enfrentados principalmente pelos municípios, em relação ao gerenciamento e pagamento das despesas.

k) Orientar os conselhos municipais de educação para que se tornem órgãos normatizadores do ensino público municipal e das instituições privadas de educação infantil, no contexto do SNE.

231 Para se avançar na consolidação de políticas de financiamento que contribuam para a melhoria da educação nacional, em todos os níveis, faz-se necessário:

a) Desvincular os recursos destinados à educação de qualquer nível de contingenciamento de recursos provenientes das receitas da União;

b) Revogar, de imediato, a DRU para todas as áreas sociais;

c) Garantir o aumento dos recursos da educação de $18 \%$ para, no mínimo, $20 \%$ (da União) e de 25\% para, no mínimo, 30\% (de estados, DF e municípios) não só da receita de impostos, mas 
adicionando-se, de forma adequada, percentuais das taxas e contribuições para investimento em manutenção e desenvolvimento do ensino público;

d) Efetivar a responsabilização administrativa e fiscal dos gestores públicos que não executem a integralidade dos recursos orçamentários destinados à educação e a perda do mandato nos termos da legislação em vigor (Lei 101C);

e) Retirar as despesas com aposentadorias e pensões da conta dos recursos vinculados à manutenção e desenvolvimento do ensino da União, estados, DF e municípios, garantindo a paridade entre aposentados e ativos, mantido, entretanto, o pagamento das aposentadorias e pensões nos orçamentos das instituições educacionais.

Para se avançar na consolidação de políticas de financiamento que contribuam para a melhoria da educação nacional, em todos os níveis, faz-se necessário:

a) Desvincular os recursos destinados à educação de qualquer nível de contingenciamento de recursos provenientes das receitas da União, bem como de estados, Distrito Federal e municípios.

b) Revogar, de imediato, a DRU para todas as áreas sociais.

c) Garantir o aumento dos recursos da educação de $18 \%$ para, no mínimo, $\mathbf{2 5 \%}$ da União e de 25\% para, no mínimo, $30 \%$ (de estados, DF e municípios) não só da receita de impostos, mas adicionando-se, de forma adequada, percentuais das taxas e contribuições sociais para investimento em manutenção e desenvolvimento do ensino público.

c) Ampliar o investimento em educação pública em relação ao PIB, na proporção de, no mínimo, $1 \%$ ao ano, de forma a atingir, no mínimo, $7 \%$ do PIB até 2011 e, no mínimo, $10 \%$ do PIB até 2014, respeitando a vinculação de receitas à educação definidas e incluindo, de forma adequada, todos os tributos (impostos, taxas e contribuições). [Repetição de ação anterior]

d) Efetivar a responsabilização administrativa e fiscal dos/das gestores/as públicos/as que não executem a integralidade dos recursos orçamentários destinados à educação e a perda do mandato nos termos da legislação em vigor (Lei $101 \mathrm{C}$ ), inclusive para os gestores que não cumpram os percentuais para a Manutenção e Desenvolvimento do Ensino previstos nas constituições estaduais e leis orgânicas municipais e Distrital.

e) Retirar as despesas com aposentadorias e pensões da conta dos recursos vinculados à manutenção e desenvolvimento do ensino da União, estados, DF e municípios, garantindo a paridade entre aposentados/as e ativos/as, mas mantendo o pagamento das aposentadorias e pensões nos orçamentos das instituições educacionais.

232 No tocante ao financiamento da educação brasileira, destaca-se, nos últimos anos, a criação do Fundeb, ocorrida com forte participação da sociedade civil organizada, iniciativa importante na implantação da política nacional direcionada à articulação dos entes federados, na descentralização do sistema educativo, bem como na valorização do magistério público.

No tocante ao financiamento da educação brasileira, destaca-se, nos últimos anos, a criação do Fundeb, ocorrida com forte participação da sociedade civil organizada, iniciativa importante na implantação da política nacional direcionada à articulação dos entes federados, na descentralização do sistema educativo, bem como na valorização do magistério público.

233 O Fundeb, ao substituir o Fundef, trouxe pelo menos duas vantagens:1) aumentou substancialmente o compromisso da União com a educação básica, ampliando o aporte, a título de complementação, de cerca de R $\$ 500$ milhões (média no Fundef) para cerca de R $\$ 5$ bilhões de investimento ao ano; e 2) instituiu um único fundo para toda a educação básica e não apenas para o ensino fundamental. 
O Fundeb, ao substituir o Fundef, trouxe pelo menos duas vantagens: 1) aumentou substancialmente o compromisso da União com a educação básica, ampliando o aporte, a título de complementação, de cerca de R $\$ 500$ milhões (média no Fundef) para cerca de R 5 bilhões de investimento ao ano; e 2) instituiu um único fundo para toda a educação básica e não apenas para o ensino fundamental. No entanto, é urgente o ressarcimento da União - em valores atualizados - à sociedade brasileira, estados, DF e municípios pelo não cumprimento dos critérios legais para o cálculo do valor aluno/a/ano do Fundef (Lei 9424/ 96). A dívida já supera os $R$ \$ 20 bilhões de reais e deve ser paga imediatamente aos estados e municípios, que deverão obrigatoriamente investir os valores a serem recebidos na melhoria da qualidade do ensino de suas redes. Essa dívida educacional não pode ser paga ou descontada por meio de perdão da dívida tributária desses entes federados para com a União.

234 Trata-se, no que diz respeito à educação básica, de uma expressão da visão sistêmica da educação, ao financiar todas as suas etapas, da ereche ao ensino médio, e ao reservar parcela importante dos recursos para a educação de jovens e adultos. É também expressão de uma visão de ordenamento do território e de desenvolvimento social e econômico, na medida em que a complementação da União é direcionada às regiões nas quais o investimento por aluno é inferior à média nacional.

No que diz respeito à educação básica, a implantação do Fundeb representa a visão sistêmica da educação, ao financiar todas as suas etapas, da educação infantil ao ensino médio, e ao reservar parcela importante dos recursos para a educação de jovens e adultos. É também a expressão de uma visão de ordenamento do território e de desenvolvimento social e econômico, na medida em que a complementação da União é direcionada às regiões nas quais o investimento por estudante é inferior à média nacional.

235 Três inovações foram incorporadas ao financiamento da educação básica, sendo as duas primeiras referentes ao Fundeb: 1) a diferenciação dos coeficientes de remuneração das matrículas não se dá apenas por etapa e modalidade da educação básica mas também pela extensão do turno: a escola de tempo integral recebe $25 \%$ a mais por aluno matriculado; 2) a creche conveniada foi contemplada para efeito de repartição dos recursos do fundo - a atual taxa de atendimento da educação infantil, em especial na creche,

dadas as metas expressas no PNE, justifica, nesse caso, a parceria do poder público com o segmento comunitário; e 3)a atenção à educação infantil é complementada pelo ProInfância, programa que financia a expansão da rede fúsica de atendimento da ducação infantil públiea.

Duas inovações foram incorporadas ao financiamento da educação básica, referentes ao Fundeb: 1) a diferenciação dos coeficientes de remuneração das matrículas não se dá apenas por etapa e modalidade da educação básica, mas também pela extensão do turno: a escola de tempo integral recebe $25 \%$ a mais por estudante matriculado/a; 2) a creche conveniada foi contemplada para efeito de repartição dos recursos do fundo - a atual taxa de atendimento da educação infantil, em especial na creche, dadas as metas expressas no PNE, justifica, nesse caso, a parceria do poder público com o segmento conveniado.

Contudo, em respeito ao princípio do recurso público para a escola pública, o número de matrículas em creches conveniadas deve ser congelado em 2014, e essa modalidade de parceria deve ser extinta até 2018, tendo que ser obrigatoriamente assegurado o atendimento da demanda diretamente na rede pública. Vale dizer que no caso da educação infantil, a extensão da obrigatoriedade do ensino não pode significar prejuízo de investimentos na ampliação de matrículas nas creches - primeira etapa da educação básica 
e aquela que está mais distante de atingir as metas de atendimento estabelecidas pelo PNE. Nessa ótica, é fundamental a garantia de aporte financeiro do Governo Federal para construção, reforma, ampliação e custeio com pessoal para o aumento significativo da oferta de vagas. $O$ objetivo é matricular $50 \%$ das crianças de 0 a 3 anos, até 2012, e universalizar o atendimento da demanda manifesta, até 2016.

236 O Fundeb se pauta, ainda, pela universalização do atendimento à educação, no acréscimo de $15 \%$ para $20 \%$ do FPE, FPM, ICMS, IPI, EXP*, lei complementar 87, mais ${ }^{* *}$ o IPVA, ITBI ${ }^{* * *}$ e ITR $^{* * * * *}$, e o acompanhamento e avaliação da sociedade, realizado por meio dos conselhos do Fundeb, tende a melhorar a transparência e a fiscalização dos recursos aplicados Ainda como recursos da educação, devem ser acrescentados os $5 \%$ dos mesmos impostos do fundo que não foram vinculados e os $25 \%$ dos impostos próprios, estaduais e municipais.

O Fundeb se pauta ainda pela universalização do atendimento à educação, no acréscimo de $15 \%$ para $20 \%$ do FPE, FPM, ICMS, IPI, EXP, lei complementar 87, IPVA, ITBI e ITR e o acompanhamento e avaliação da sociedade, realizado por meio dos conselhos do fundo, tendendo a melhorar a transparência e a fiscalização dos recursos aplicados em educação. Ainda como recursos da educação, devem ser acrescentados os 5\% dos mesmos impostos do fundo que não foram vinculados e os $25 \%$ dos impostos próprios, estaduais, distrital e municipais. [repete os mesmos erros do documento de referêncial

237 Nesse contexto, o Fundeb não atendeu a todas as expectativas dos trabalhadores em educação, mas foi um avanço em relação ao antigo Fundef, que priorizava apenas o ensino fundamental e discriminava a educação infantil e o ensino médio, fragmentando, conseqüentemente, a luta dos trabalhadores em educação.

Nesse contexto, o Fundeb não atendeu a todas as expectativas da sociedade civil, em especial dos/das trabalhadores/as em educação, mas foi um avanço em relação ao antigo Fundef, que priorizava apenas o ensino fundamental e discriminava a educação infantil e o ensino médio, fragmentando, consequentemente, a luta dos movimentos sociais e dos/das trabalhadores/as em educação.

238 Entretanto, o Fundeb, pør si sé, não é suficiente para garantir a universalização da oferta de vagas na educação básica e tampouco a permanência do aluno na escola até a conclusão do ensino médio com qualidade, o que exige a aplicação de recursos financeiros na educação básica para além desse fundo.

Entretanto, o Fundeb, como visto, não é suficiente para garantir a universalização da oferta de vagas na educação básica e tampouco a permanência do/da estudante na escola até a conclusão do ensino médio com qualidade, o que exige a aplicação de recursos financeiros na educação básica para além desse fundo.

\footnotetext{
* sic - o certo é $20 \%$ das cotas estaduais e municipais do IPI-exp., que correspondem a apenas $10 \%$ de toda a receita do IPI-exportação, pois $90 \%$ ficam com o governo federal.

*** sic - o certo é $20 \%$ do.

**** sic - o certo é ITCD, imposto estadual. O ITBI é imposto municipal e não entra no Fundeb.

***** sic - o correto é $20 \%$ da cota municipal do ITR (= $50 \%)$, pois $50 \%$ correspondem à cota federal.

***** sic - o correto seria dizer $25 \%$ dos impostos estaduais não incluídos no Fundeb, pois há impostos estaduais próprios (ICMS, IPVA e ITCD) contabilizados no Fundeb com o percentual de 20\%, e não de $25 \%$. Esqueceu de mencionar as receitas adicionais ao mínimo, como o ganho com o Fundeb, o salário-educação, e transferências federais para programas como o de alimentação escolar, transporte escolar, etc.
} 
Nesse sentido, em perspectiva, entende-se a importância de transformar o Fundeb em um fundo nacional, com igual per capita para todos os Estados, com a aplicação de parte ainda mais significativa dos recursos vinculados à educação e incorporando também outras formas de arrecadação, não só os impostos. Deve-se, também, tomar como referência o maior per capita existente no País, com o objetivo de unificar o valor aluno/a por ano executado no Brasil, acabando com as desigualdades por Estado. O Fundeb, para isso, deve ter como referência o estabelecimento de um Custo Aluno/a - Qualidade (CAQ), nivelando todos os CAQs, a partir do valor máximo alcançado e praticado nos estados com maior arrecadação.

239 Acredita-se, contudo, que os recursos daí auferidos, se bem aplicados e fiscalizados adequadamente, com a participação dos conselhos de acompanhamento, instituídos no âmbito dos estados e municípios, poderão constituir um novo mareo de financiamento para as diversas etapas de ensino e modalidades da educação básica. Estima-se, com isso, que ocorra o aumento da matrícula nas diversas etapas da educação, asseguradas a aplicação e a otimização dos percentuais vinculados à manutenção e desenvolvimento do ensino, especialmente com a participação mais efetiva da União.

Acredita-se, contudo, que os recursos hoje contabilizados no Fundeb, se bem aplicados e fiscalizados adequadamente, com a participação dos conselhos de acompanhamento, instituídos no âmbito dos estados, DF e municípios, poderão constituir avanços no financiamento para as diversas etapas de ensino e modalidades da educação básica. Estima-se, com isso, que ocorra o aumento da matrícula nas diversas etapas da educação, asseguradas a aplicação e a otimização dos percentuais vinculados à manutenção e ao desenvolvimento do ensino, especialmente com a participação mais efetiva da União. Contudo, para tanto, deve-se assegurar que os fatores de ponderação do Fundeb representem os custos efetivos de cada etapa ou modalidade de ensino.

240 Para se fazer com que o Fundeb possa colaborar efetivamente para elevar a qualidade da educação, a referência de gasto por aluno/ano do novo fundo deve ser uma verdadeira política de custo-aluno-qualidade, construída em parceria com a sociedade civil, como uma das principais referências no âmbito do financiamento da educação.

Para se fazer com que o Fundeb possa colaborar efetivamente para elevar a qualidade da educação, a referência de investimento por estudante/ano do fundo deve, necessariamente, passar a ser uma verdadeira política de custo-aluno/a-qualidade, ancorada pela União e construída em parceria com a sociedade civil, como uma das principais referências no âmbito do financiamento da educação.

241 O valor mínimo do Fundeb, em cada nível, etapa e modalidade de educação, deve garantir a presença, em todas as escolas públicas do País, dos arâmetes de qualidade previstos no PNE e na $\mathrm{LDB}$, além de outros que precisam ser definidos no regime de colaboração.

O valor mínimo do Fundeb, em cada nível, etapa e modalidade de educação, deve assim garantir a presença, em todas as escolas públicas do País, dos padrões mínimos de qualidade previstos no PNE e na LDB, além de outros que precisam ser definidos no regime de colaboração.

242 Com relação especificamente ao Fundeb, as seguintes ações devem ser asseguradas: 
a) Consolidar o Fundeb, garantindo recursos financeiros adequados por estudante, e que resulte em real ampliação dos recursos vinculados à educação, incorporando, de forma adequada, além dos impostos, taxas e contribuições; [sicl

b) Considerar as condições reais de cada etapa e modalidade de ensino, nos fatores de ponderação do valor por aluno do Fundeb, considerando: relação aluno/ turma; presença de infra-estrutura e insumos adequados; qualificação dos profissionais de educação; presença de jornada em tempo integral dos alunos etc;

c) Fortalecer e regulamentar o papel fiscalizador dos conselhos de acompanhamento e de avaliação do Fundeb, considerando a composição e suas atribuições legais;

d) Tornar públicas e transparentes as receitas e despesas do total de recursos destinados à educação em cada sistema público * de ensino federal, distrital, estadual e municipal e assegurar a efetiva fiscalização da aplicação desses recursos por meio dos conselhos, do Ministério Público, tribunais de contas estaduais e municipais e dos diversos setores da sociedade;

e) Constituir as secretarias de educação municipais, estaduais e do DF como unidades orçamentárias, em conformidade com o artigo 69 da LDB, com a garantia de que os dirigentes da pasta educacional sejam gestores plenos dos recursos vinculados, sob o acompanhamento, controle e fiscalização de conselhos, tribunais de contas estaduais e municipais e demais órgãos fiscalizadores;

f) Garantir, em articulação com os tribunais de contas, a formação dos conselheiros do Fundeb no âmbito de todos os estados e municípios, para que tenham uma atuação qualificada no acompanhamento, avaliação e controle fiscal dos recursos, por meio de cursos permanentes, provendo-lhes suporte técnico contábil e jurídico, a fim de que exerçam com maior autonomia e segurança as suas funções;

g) Apoiar a criação e/ou consolidação de conselhos estaduais e municipais de educação, assegurando dotação orçamentária ao seu custeio e à capacitação dos conselheiros, para garantir o acompanhamento e controle social dos recursos vinculados a educação;

h) Ampliar e consolidar as políticas de financiamento e expansão da educação profissional, com ênfase no ensino médio integrado, na educação tecnológica, na formação de professores e no desenvolvimento da pesquisa e da inovação, considerando as necessidades produtivas, sociais e de inserção profissional.

Em se tratando do financiamento da educação básica e especialmente do Fundeb, as seguintes ações devem ser asseguradas:

a) Consolidar o Fundeb - garantindo recursos financeiros adequados por estudante -, de modo que resulte em real ampliação dos recursos vinculados à educação, incorporando, de forma adequada, impostos, taxas e contribuições.

b) Alterar a lei do Fundeb no sentido de retirar o sistema de balizas que limitam os fatores de ponderação do fundo a uma escala de 0,7 a 1,3 . Esta medida é imprescindível para substituir a atual perspectiva do gasto-aluno/a/ano ou custo-aluno/a/ano existente no fundo, por uma política de custo-aluno/a-qualidade. Concomitantemente, a complementação da União ao Fundeb deve avançar imediatamente para uma transferência equivalente a $1 \%$ do PIB/ ano.

c) Considerar as condições reais e os custos de cada etapa e modalidade de ensino, nos fatores de ponderação do valor por estudante do Fundeb, considerando: relação estudante/turma; presença de infraestrutura e insumos adequados; qualificação dos/das profissionais de educação; presença de jornada em tempo integral dos/das estudantes etc.

d) Fortalecer e regulamentar o papel fiscalizador dos conselhos de acompanhamento e de avaliação do Fundeb, considerando a composição e suas atribuições legais.

\footnotetext{
* sic - Pela LDB, todo sistema de ensino é público, pelo menos no sentido de estatal. Provavelmente, o documento quis dizer rede pública, que abarca apenas uma parte do sistema, a mantida pelo Poder "Público".
} 
e) Tornar públicas e transparentes as receitas e despesas do total de recursos destinados à educação em cada sistema público de ensino federal, distrital, estadual e municipal e assegurar a efetiva fiscalização da aplicação desses recursos por meio dos conselhos, do Ministério Público, tribunais de contas estaduais, distrital e municipais e dos diversos setores da sociedade.

f) Constituir as secretarias de educação municipais, estaduais e distrital como unidades orçamentárias, em conformidade com o artigo 69 da LDB, com a garantia de que os/as dirigentes da pasta educacional sejam gestores/as plenos dos recursos vinculados, sob o acompanhamento, controle e fiscalização de conselhos, tribunais de contas estaduais, distrital, municipais e demais órgãos fiscalizadores.

g) Garantir, em articulação com os tribunais de contas, a formação dos conselheiros/as do Fundeb no âmbito de todos os estados, DF e municípios, para que tenham uma atuação qualificada no acompanhamento, avaliação e controle fiscal dos recursos, por meio de cursos permanentes, provendo-lhes suporte técnico contábil e jurídico, a fim de que exerçam com maior autonomia e segurança as suas funções, sendo que a primeira formação deve ocorrer imediatamente após a sua eleição.

h) Apoiar a criação e/ou consolidação de conselhos estaduais, distrital e municipais de educação, assegurando dotação orçamentária ao seu custeio e à capacitação dos conselheiros/as, para garantir o acompanhamento e controle social dos recursos vinculados à educação.

i) Ampliar e consolidar as políticas de financiamento e expansão da educação profissional, com ênfase no ensino médio integrado, na educação tecnológica, na formação de professores/as e no desenvolvimento da pesquisa e da inovação, considerando as necessidades produtivas, sociais e de inserção profissional.

j) Financiar a compra de transportes adequados ao atendimento de estudantes com deficiência.

l) Considerando o princípio legal da educação inclusiva, apesar do importante papel desempenhado pelas organizações filantrópicas privadas, comunitárias e confessionais nas últimas décadas, deve-se hoje compreender essas organizações como estabelecimentos assistenciais e não escolares. Nesse sentido, como cabe ao Fundeb investir apenas em educação, deve-se congelar as atuais matrículas em 2014 e extingui-las até 2018, tendo que ser obrigatoriamente assegurado o atendimento da demanda diretamente na rede pública.

m) Defender e encaminhar proposta de equivalência dos percentuais da EJA no Fundeb aos demais da educação básica, ampliando recursos financeiros a ela destinados, melhorando o sistema distributivo, e promovendo condições de qualidade e ampliação de matrículas na EJA.

n) Revisar as restrições às matrículas em EJA no Fundeb, especialmente a que limita as matrículas nessa modalidade em $\mathbf{1 5 \%}$ do total de matrículas do fundo.

243 Com relação ao financiamento da educação superior, as seguintes ações devem ser asseguradas:

a) Realizar estudos para estabelecer um Fundo de Manutenção e Desenvolvimento da Educação Superior Pública, vinculando, de forma adequada, recursos dos impostos, taxas e contribuições, de modo a efetivar a autonomia universitária prevista na CF/1988;

b) Estabelecer parâmetros para a distribuição dos recursos entre as instituições públicas federais que considerem, em seu conjunto, as diversas atividades desenvolvidas pelas instituições;

c) Definir as condições a serem satisfeitas por estados, distrito federal e municípios para demandar em recursos do Fundo de Manutenção e Desenvolvimento da Educação Superior Pública;

d) Garantir recursos orçamentários para que as universidades públicas federais possam definir e executar seus próprios projetos de pesquisa, propiciando uma efetiva autonomia de pesquisa; 
e) Alocar recursos financeiros específicos para a expansão da graduação nas instituições públicas federais, no período noturno, com a condição de que o número de vagas no período noturno se iguale ao número de vagas no período diurno;

f) Definir parâmetros que expressem a qualidade da instituição de educação superior e estabelecer que volume mínimo de recursos financeiros deveria ser alocado para que as atividades de ensino (graduação e pós-graduação), pesquisa e extensão reflitam a qualidade estabelecida;

g) Estabelecer programas de apoio à permanência dos estudantes nas instituições públicas, considerando-se que há a necessidade de provocar uma grande expansão dos cursos de graduação presenciais.

Com relação ao financiamento da educação superior, as seguintes ações devem ser asseguradas: a) Realizar estudos para estabelecer um Fundo de Manutenção e Desenvolvimento da Educação Superior Pública, vinculando, de forma adequada, recursos dos impostos, taxas e contribuições, de modo a efetivar a autonomia universitária prevista na CF/1988.

b) Estabelecer parâmetros para a distribuição dos recursos entre as instituições públicas que considerem, em seu conjunto, as diversas atividades desenvolvidas pelas instituições.

c) Definir as condições a serem satisfeitas por estados, distrito federal e municípios para demandarem recursos do Fundo de Manutenção e Desenvolvimento da Educação Superior Pública.

d) Garantir recursos orçamentários para que as universidades públicas possam definir e executar seus próprios projetos de pesquisa, propiciando uma efetiva autonomia de pesquisa.

e) Alocar recursos financeiros específicos para a expansão da graduação nas instituições públicas no período noturno, com a condição de que o número de vagas nesse período seja $1 / 3$ (um terço) do número total de vagas.

f) Definir parâmetros que expressem a qualidade da instituição de educação superior e estabelecer que o volume mínimo de recursos financeiros seja alocado para que as atividades de ensino (graduação e pós-graduação), pesquisa e extensão reflitam a qualidade estabelecida. ${ }^{*}$

g) Estabelecer programas de apoio à permanência dos/das estudantes nas instituições públicas, considerando-se que há a necessidade de provocar uma grande expansão dos cursos de graduação presenciais.

h) Ampliar a discussão sobre a política do ProuniI e do Reuni, para que os recursos públicos destinados a estes programas possam ser revertidos à ampliação, melhoria e reestruturação das instituições públicas de ensino superior, fortalecendo seu caráter público, gratuito e de qualidade.

i) Garantir orçamentos às políticas de acesso e permanência na educação superior para inclusão dos negros, povos indígenas, além de outros grupos e extratos ${ }^{* * *}$ sociais $^{2}$ historicamente excluídos desse nível de ensino.

j) Garantir financiamento do governo federal ou estadual nos campi universitários públicos para oferta de curso de graduação, pós-graduação, mestrado e doutorado aos/às profissionais da educação.

244 Quanto à organicidade das políticas de financiamento, dentre as várias questões que se colocam envolvendo o sistema nacional articulado de educação, deve-se destacar, ainda, a necessidade de ampla reforma tributária, que contribua para a ampliação e melhor distribuição das receitas destinadas à educação. Para tanto, é preciso que os setores educacionais pressionem e colaborem com o Congresso Nacional na construção de uma reforma tributária ampla e justa

\footnotetext{
* sic - a inclusão do artigo 'o' mudou o sentido do DR.

*** sic - o correto é estratos.
}

Revista HISTEDBR On-line, Campinas, n.39, p. 321-345, set.2010 - ISSN: 1676-2584 
socialmente, que iniba as políticas de renúncia e guerra fiscal, responsáveis por grave prejuízo ao investimento de recursos nas áreas sociais, em especial na educação.

Quanto à organicidade das políticas de financiamento, dentre as várias questões que se colocam envolvendo o Sistema Nacional de Educação, deve-se reiterar, ainda, a necessidade de ampla reforma tributária, que contribua para a ampliação e melhor distribuição das receitas destinadas à educação. Para tanto, é preciso que os setores educacionais pressionem e colaborem com o Congresso Nacional na construção de uma reforma tributária ampla e justa socialmente, que iniba as políticas de renúncia e guerra fiscal, responsáveis por grave prejuízo ao investimento de recursos nas áreas sociais, em especial na educação.

245 Essa reforma tributária deve estabelecer que não só os impostos, mas todos os tributos (impostos, taxas e contribuições) do orçamento fiscal, de forma adequada, façam parte da vinculação de recursos à educação. Nesse sentido, é fundamental preservar no contexto da reforma tributária a vinculação de recursos e , no mínime, os atuais percentuais constitucionais e, impedindo a desvinculação de recursos da educação.

Essa reforma tributária deve estabelecer que não só os impostos, mas todos os tributos (impostos, taxas e contribuições) do orçamento fiscal façam parte da vinculação de recursos à educação pública, além dos dividendos [sic] advindos de multas. Nesse sentido, é fundamental aumentar e garantir, no contexto da reforma tributária, a vinculação de recursos ampliando os atuais percentuais constitucionais e impedindo a desvinculação de recursos da educação. A contribuição social do Salário-Educação deve ser preservada como um recurso fundamental para a educação pública brasileira.

246 O financiamento tem como base e pressuposto as opções de política fiscal e tributária. Por isso, nas reformas legais dessas áreas deve ser levada em conta a ampliação dos recursos à educação. Há que fiscalizar para garantir o cumprimento da arrecadação em todos os entes federados; a redução do superávit fiscal deve resultar em benefício para o desenvolvimento das políticas sociais.

O financiamento tem como base e pressuposto as opções de política fiscal e tributária. Por isso, nas reformas legais dessas áreas, deve ser levada em conta a ampliação dos recursos à educação. De todo modo, é preciso fiscalizar a arrecadação e garantir a correta aplicação por todos os entes federados dos recursos devidos à área, promovendo-se a transparência do uso nos recursos públicos. Além disso, o fim do superávit fiscal e superávit primário deve resultar em benefício para o desenvolvimento das políticas sociais.

247 É necessária a realização de uma reforma tributária que crie um modelo mais justo que o atual, tributando o capital especulativo, as grandes fortunas (imposto ainda não regulamentado), o latifúndio improdutivo e o capital financeiro, além de reduzir as disparidades regionais na distribuição da receita tributária.

É necessária, assim, a realização de uma reforma tributária que crie um modelo mais justo que o atual, tributando o capital especulativo, as grandes fortunas (imposto ainda não regulamentado), o latifúndio improdutivo e o capital financeiro, além de reduzir as disparidades regionais na distribuição da receita tributária.

248 É imperativo, pois, enfrentar o principal problema do financiamento educacional no País - a falta de recursos -, exercendo acompanhamento e controle social para que sejam devidamente 
aplicados. Para superar a fragmentação e o isolamento das políticas educacionais é preciso criar um sistema nacional articulado de educação que, através do regime de colaboração, garanta os recursos necessários a educação pública com qualidade social.

É imperativo, pois, enfrentar o principal problema do financiamento educacional no País - a falta de recursos suficientes -, exercendo acompanhamento e controle social para que sejam devidamente aplicados. Para superar a fragmentação e o isolamento das políticas educacionais, é preciso criar um sistema nacional de educação que, através do regime de colaboração, garanta os recursos necessários à educação pública com qualidade social.

249 O exemplo da política de financiamento da educação básica, por meio dos fundos, apresentou a possibilidade de melhorar os salários, reduzir as desigualdades, avançar na formação. Porém, como há insuficiência de recursos, existe um longo caminho a percorrer para que as melhorias focalizadas e pontuais sejam amplas e permanentes.

250 Ressalte-se, mais uma vez, que a construção do regime de colaboração entre os sistemas de ensino é uma luta histórica dos educadores e de toda a sociedade brasileira e que precisa ser aprimorado e devidamente financiado. Deve-se compreender, portanto, a necessidade de sua construção e Implementação, por meio de uma legislação clara sobre as regras, em que os custos sejam devidamente compartilhados e pautados por uma política nacional de educação, referenciada na unidade nacional, dentro da diversidade. Essa política deve fortalecer o relacionamento entre os órgãos normativos, permitindo uma equivalência nas diretrizes próprias de valorização dos profissionais, bem como na definição de instrumentos básicos para o perfeito desenvolvimento do ensino, em todas as suas necessidades.

Ressalte-se, mais uma vez, que a construção do regime de colaboração entre os sistemas de ensino é uma luta histórica dos/das educadores/as e de toda a sociedade brasileira e que precisa ser aprimorado e devidamente financiado. Deve-se compreender, portanto, a necessidade de sua construção e implementação, por meio de uma legislação clara sobre as regras, em que os custos sejam devidamente compartilhados e pautados por uma política nacional de educação, referenciada na unidade nacional, dentro da diversidade. Essa política deve fortalecer o relacionamento entre os órgãos normativos, permitindo uma equivalência nas diretrizes próprias de valorização dos/das profissionais, bem como na definição de instrumentos básicos para o perfeito desenvolvimento do ensino, em todas as suas necessidades.

Deve-se destinar cinquenta por cento $(50 \%)$ dos créditos advindos do pagamento de royalties decorrentes de atividades de produção energética (extração, tratamento, armazenagem e refinamento de hidrocarbonetos) à manutenção e desenvolvimento do ensino (MDE).

Como outra nova e importante fonte de recursos para a área educacional, os valores financeiros que compõem o Fundo Social advindos da exploração da camada pré-sal devem ter uma destinação na ordem de $\mathbf{5 0 \%}$ de suas receitas para a educação, tendo, desse modo, vinculação imediata ao orçamento do MEC, ou seja, não devem passar por deliberação do Comitê Gestor do Fundo Social. Desse total acumulado, 30\% devem ficar com a União, para o desenvolvimento de programas relativos ao ensino superior e profissionalizante $\mathrm{e}$ 70\% devem ser transferidos a estados, distrito federal e municípios, para o desenvolvimento de programas de educação básica por meio de uma política de transferências equivalente ao salário educação. É importante ressaltar que devem ser priorizados os estados e municípios com baixo IDH. Apenas dessa forma a riqueza do présal poderá beneficiar efetivamente todos os brasileiros e todas as brasileiras. 
No tocante à educação fiscal deve-se: garantir que os conteúdos da educação fiscal para cidadania componham currículo obrigatório na formação dos/as profissionais de educação, em todos os níveis, etapas e modalidades de ensino; possibilitar que o Sistema Nacional de Educação e as entidades da sociedade civil organizada, órgãos públicos de controle e fiscalização, escolas de governo e demais parceiros atuem articulados às ações e projetos de educação fiscal; estimular atividades práticas para o exercício da cidadania e do controle social assegurando a participação popular na gestão do Estado; fomentar o debate em torno das políticas públicas capazes de reduzir as desigualdades sociais; ser um instrumento de promoção permanente do Estado Democrático de Direito; difundir informações que possibilitem a construção da consciência cidadã em torno do papel social dos tributos, dos bens e orçamentos públicos; informar à sociedade, sobre os efeitos lesivos da corrupção, da sonegação físcal e da má gestão dos recursos públicos; e, garantir financiamento de programas de extensão, pesquisas e projetos de servidores públicos, com vistas à construção de conhecimentos relativos à educação fỉscal. 